\title{
SETTLING FOR COUPONS: \\ DISCOUNT CONTRACTS AS \\ COMPENSATION AND PUNISHMENT \\ IN ANTITRUST LAWSUITS
}

Severin Borenstein

Working Paper No. 5085

\section{NATIONAL BUREAU OF ECONOMIC RESEARCH 1050 Massachusetts Avenue \\ Cambridge, MA 02138 April 1995}

I thank Aaron Edlin, Joe Farrell, and seminar participants at U.C. Berkeley and U.C. Santa Barbara for helpful comments. Victor Stango provided excellent research assistance. Any remaining errors are my own. This paper is part of NBER's research program in Industrial Organization. Any opinions expressed are those of the author and not those of the National Bureau of Economic Research.

(C) 1995 by Severin Borenstein. All rights reserved. Short sections of text, not to exceed two paragraphs, may be quoted without explicit permission provided that full credit, including (C) notice, is given to the source. 


\title{
SETTLING FOR COUPONS: \\ DISCOUNT CONTRACTS AS \\ COMPENSATION AND PUNISHMENT \\ IN ANTITRUST LAWSUITS
}

\begin{abstract}
A number of recent antitrust lawsuits have been settled with discount contracts in which the defendants agree in the future to sell to the plaintiffs at a discount off of the price they offer to other buyers. Economists often object to such settlements, arguing that the sellers will partially or fully offset these discounts by increasing the baseline price from which the discount is calculated. This paper shows that poorly structured discount contracts will indeed result in price increases for other buyers and that other buyers, not the sellers, are likely to bear most of the cost imposed by the settlement. Carefully formulated discount settlements, however, can avoid giving the sellers an incentive to raise prices to buyers not covered by the settlement. In such cases, the defendant bears the full cost of the settlement. I suggest that poorly structured settlements still take place because their costs are borne primarily by consumers who are not parties to these cases.
\end{abstract}

Severin Borenstein U.C. Energy Institute 2539 Channing Way Berkeley, CA $94720-5180$ and NBER 


\section{Introduction}

A discount contract is an agreement that a company will sell to a buyer at a given discount off of the price that it offers to other buyers. Compared to the price charged to other buyers (which I will call the "retail price") a discount can be specified as a percentage off or it can be a fixed monetary discount, e.g., fifty dollars. ${ }^{1}$ Discount contracts are commonly used by large purchasers, including many government agencies, in buying from companies that also sell at a posted retail price to many other consumers.

Recently, many settlements of antitrust lawsuits have utilized such contracts in the form of discount coupons. In 1994, settlement of a class action lawsuit for price-fixing against the major U.S. airlines was concluded with the airlines issuing more than $\$ 400$ million in discount coupons to consumers who demonstrated that they purchased certain air travel between January 1988 and June 1992. Circa Pharmaceuticals settled a class-action price-fixing suit in 1994 by issuing $\$ 2.5$ million in coupons that permit former customers to purchase Circa products at a discount. ${ }^{2}$ Xerox settled a lawsuit in 1993 - regarding claims that it refused to sell parts to competing service providers in order to lock them out of the equipment service business - by issuing $\$ 225$ million in "transferable certificates"

1 Throughout this paper, I focus on monetary discounts. An earlier draft showed that the conclusions also hold for percentage discounts.

2 See Wall Street Journal, July 11, 1994. 
to service providers and owners of Xerox equipment. ${ }^{3}$ General Motors agreed in 1994 to settle a lawsuit over the safety of the gas tanks in certain of its pickup trucks by issuing $\$ 1000$ coupons to owners of these trucks which would be good towards purchase of a new GM truck. ${ }^{45}$

Some of "coupon settlements" clearly facilitate price discrimination by the seller since the coupons are of such low value that a significant proportion of possible beneficiaries would not find it worth the time or hassle to use the coupons even if they bought the product. This was almost surely the case in a price-fixing case against a soft drink bottler that was settled by requiring that the bottler attach $20 \phi$-off coupons to 250,000 of its two-liter bottles. ${ }^{6}$ In the cases discussed above, however,

3 See Geyelin, 1993.

4 See Lavin, 1993.

5 Other cases include: a 1992 settlement against 5 bulk popcorn distributors accused of price-fixing that included \$2.1 million of discount coupons, a 1995 settlement of a price-fixing case against four Houston plumbing supply dealers that included $\$ 1.5$ million in discount coupons, and a 1993 case against three oil companies for fixing gasoline prices that included distribution of $\$ 11.5$ million discount coupons for gasoline to businesses in four western states.

6 Predictably, that settlement was reported by the press and the defendant to be worth $\$ 50,000$. The 1994 settlement of a price-fixing case against the makers of Brillo and S.O.S. soap pads also included cents-off coupons. A coupon settlement of vertical price-fixing case against Nintendo in 1991 probably facilitated price discrimination. That case was settled with Nintendo issuing up to 5 million coupons for $\$ 5$ off of its game cartridges. See Barrett, 1991. Cuisinart's 1983 settlement of a vertical price-fixing case involved issuing about a million coupons good for one-half off the suggested retail price of 
the coupons were of sufficient value that virtually all people buying the product who have access to coupons would use them. Furthermore, plaintiffs (or their lawyers) and the courts generally resist the price discrimination interpretation, asserting that the discounts would not have been offered otherwise and the victims of the antitrust violation would not have been compensated. Assisting the defendants' in sorting consumers is clearly not the goal of the legal process in these cases. In the analysis here, I give coupon settlements the benefit of this doubt and assume that elasticities do not differ between the aggregate demands of the groups that do and do not use the discounts.

Even absent an elasticity-based motivation for sellers to price discriminate, economists frequently argue that the sellers will offset such discounts by increasing the retail price from which the discount is calculated. The incentive for sellers to respond by raising the retail price, however, depends on whether the seller views the total loss under the agreement to be sunk or, instead, believes its own behavior can reduce that loss. In the latter instance, the seller may indeed respond by raising the retail price, but it is often possible to design a settlement that does not produce incentives for such strategic behavior.

In this paper, I show that two factors are critical in deter-

Cuisinart accessories. The street price for many of these items, however, was already about one-half of the suggested retail price. See Lewin, 1983. 
mining whether a defendant will treat foregone profits under a discount contract as sunk, and therefore will not otherwise change its pricing behavior. The first is the criterion for termination of the contract. If the contract is has a binding time limit, specifying that discounts will continue until a certain date in the future, then the total foregone profits from the contract are not fixed and a firm will change its prices strategically in order to minimize the loss. In contrast, if the discounts are dollar-limited, i.e., continuing until a given total discount amount is reached - one million dollars for instance - then the firm is more likely to treat this as a sunk loss and maintain its former pricing policy.

The second factor affecting the response to a discount contract is the extent to which free-riding occurs among buyers and sellers. Even if a discount contract is dollar-limited, the foregone profits for any one firm will not be fixed if the dollar discount is pooled across many defendants. Pooling of discounts across firms will affect the incentive of any one firm to respond to a discount contract by adjusting its retail price. Pooling of the total discount settlement among buyers (or plaintiffs) also affects the profits that the sellers will forego and the incentives of sellers to adjust prices.

A common, and intuitively appealing, argument in defense of discount contracts is that competition in a market will prevent any one firm from responding to a discount contract by raising its retail price. I show that this usually will not be the 
case. In fact, time-limited discount contracts can yield lower net benefits for consumers when applied to more competitive markets.

The paper proceeds first by considering time-limited discounts. In this setting, I present the basic analytics of a discount contract. Section III investigates the effects of competition in the product market on the impact of the discount contract. In Section IV, I present the alternative, dollar-limited, discount contract and demonstrate its superior properties. In Section V, I consider the shortcomings of dollar-limited discounts when there are common pools of liability among sellers or of benefits among buyers. Section VI applies the previous analysis to some of the recent antitrust settlements that have included discount contracts. I conclude in Section VII by discussing the motivations of parties in antitrust and other civil litigation to reach "coupon settlements."

\section{Time-Limited Discount Contracts}

Most recent antitrust settlements that involved prospective discounts have utilized coupons, and so don't at first appear to be time-limited. In many of these cases, however, the coupons have expiration dates that make it very likely that not all coupons would be used if recipients continued to make their usual purchases. Some products covered are consumer durables that the buyer might not expect to buy again for a very long 
time, if ever. ${ }^{7}$ When that is the case, the analysis of a timelimited discount contract applies. Furthermore, time-limited discount contracts are common among government agencies and businesses. Many state agencies sign contracts with suppliers that guarantee a (usually percentage) discount off the vendor's retail price. ${ }^{8}$

Throughout the analysis, I assume that the designated discount buyers' demand for the product, $g(P)$ each period, is simply a given proportion, $1-\alpha$, of the total demand the seller faces, $f(P)$ per period, no more or less elastic than the market as a whole:

$$
g(P)=(1-\alpha) f(P) \quad \forall P
$$

which assures that, in the absence of the discount contract, the seller would want to charge these buyers the same price as all others. To keep the mathematics simple, I assume constant marginal cost. The conclusions clearly do not rely on this.

If the designated buyers will receive a price for one period that is a $\beta$ less than the retail price, the seller faces the

7 In most of these cases, the coupons are not transferable.

8 State governments, for instance, often sign annual contracts with airlines that guarantee a certain percentage discount off retail price for state employees. The American Economics Association is one of many groups that negotiates discount contracts with airlines for travel to and from its conventions. While these could be argued to be elasticity-based discrimination, it is not obvious that these buyers have higher market- or firm-level elasticities than the remainder of the population. 
maximization problem: ${ }^{9}$

$$
\max \Pi=(P-c) \alpha f(P)+(P-c-\beta)(1-\alpha) f(P-\beta)
$$

which implies

$$
\begin{aligned}
& \frac{\mathrm{d} \Pi}{\mathrm{d} P}=\alpha\left[f(P)+f^{\prime}(P)(P-c)\right] \\
& +(1-\alpha)\left[f(P-\beta)+f^{\prime}(P-\beta)(P-c-\beta)\right]=0
\end{aligned}
$$

The price that would be charged in the absence of the discount contract, $P^{*}$, would cause the first term in [2] to be zero, because the expression inside the square brackets of the first term would be the entire first-order condition. The expression inside the square brackets of the second term, however, is the derivative of the same profit function evaluated at a price that is $\beta$ less than $P$. If the profit function is globally concave in (a single) price, this second bracketed term is positive at $P=P^{*}$, so profits are further increased by raising retail price from $P^{*}$. This leads to the standard criticism of discount contracts: the seller will lessen the gain to the discount buyer by raising the price to all others.

Closer examination of [2] provides some further intuition about the firm's response to the discount contract. The optimal $\mathrm{P}$ occurs where the weighted average of the first-order

9 Throughout this paper, I assume that intertemporal demand shifting is not possible. That would greatly complicate the analysis without adding substantial new insight. 
condition for the non-discount group and the first-order condition for the discount group is equal to zero, with the weights being the population shares of each group, $\alpha$ and $1-\alpha$. If the second derivative of the profit function were constant around the maximum - as is the case with linear demand and constant marginal cost - then the weighted average of the new retail and discount prices would exactly equal the retail price when no discount contract was in force. More generally, the time-limited discount contract will raise or lower the overall population-weighted average price only to the extent that the third derivative of the profit function is non-zero. ${ }^{10}$

Table 1 illustrates the effect of a discount contract using a constant-elasticity market demand function, $Q=P^{\epsilon}$, with an elasticity of -3 , and constant marginal cost of production. I examine the cases in which $\beta$ is $10 \%$ and $20 \%$ of the pre-discount retail price, which are consistent with recent antitrust settlements and many other discount contracts. With this demand and cost structure, the equilibrium gain in consumer surplus for the discount group is always smaller than the loss for the remainder of the consumer population. With a discount that is $10 \%$ of the pre-contract retail price $(0.15)$, for instance, the loss to the non-discount group is about $28 \%$ larger than the gain to the discount group. This ratio is affected only slightly

10 The purchase-weighted average price will tend to fall by more than the population-weighted average price, because the discount group will increase their purchases while the non-discount group will decrease theirs. 
by the relative sizes of the two groups, staying between $27 \%$ and $30 \%$ for all $\alpha$. The change in profits is negative - this must be so, since the firm's behavior is constrained - so total surplus declines as well. For purpose of comparison later, the last two columns show the time period for which the discount is in effect and the total dollar discount during that time $\left(\left(P_{r}-P_{d}\right) \cdot Q_{d} \cdot t\right)$.

Discount contracts, however, will not always lower consumer surplus. An increased population-weighted average price is a necessary, but not sufficient, condition for a decrease in consumer surplus. With linear demand and constant marginal cost, for instance, the weighted average price is unchanged by the discount contract and consumer surplus increases, though a significant percentage of the gains to consumers in the discount group are still offset by losses to the remaining population. Profits still decline in that case by more than the net increase in consumer surplus, so total surplus declines. Thus, a discount contract may lower or raise net consumer surplus, but even when it raises consumer surplus it is likely to do so by much less than the gain to the discount group.

Table 1 also illustrates the very small impact that a timelimited discount contract is likely to have on the profits of the seller. In this instance, with demand elasticity equal to -3 , a discount of 0.15 ( $10 \%$ of the original retail price) to buyers that previously accounted for $50 \%$ of sales $(\alpha=0.5)$ will lower the profits of the seller by only $0.74 \%\left(=\frac{0.0011}{0.1481}\right)$, though the total dollar discount $(0.251)$ would be about $17 \%$ of previous profits. 
Thus, if Acme Widgets produces one million units a year at a marginal cost $\$ 1$ each and sells them for $\$ 1.50$ each, a discount of 0.15 for one year covering half the buying ropulation would be viewed generally (and by the courts) as giving $\$ 75,000$ in discounts. ${ }^{11}$ In fact, this discount would lower Acme's $\$ 500,000$ in annual profits by only $\$ 3714$. The explanation for this discrepancy is simply the shape of the profit function: profits are maximized at a price of $\$ 1.50$ in this case, but the derivative of profits with respect to price is zero at $P=\$ 1.50$, so lowering price slightly to some of the population and raising it slightly to the remainder has a small effect on profits.

Though the economic optimization problem demonstrates that the firm will raise the retail price, one might wonder whether a firm actually would. The firm might choose not to respond in this way for two reasons. First, menu costs might be such that the comparative loss in profits from maintaining the former retail price is sufficiently small that this is preferred to paying the cost of adjusting price. Discount contracts, however, are generally used in lieu of setting a specific price for the designated buyers in cases where the retail price is difficult to forecast, in particular when costs change frequently. In such cases, menu costs are unlikely to prevent reoptimization because the firm will have to adjust price frequently for other

11 This $\$ 75,000$ in total discounts ignores the demand elasticity effect of the discounted price, which is consistent with the usual way that courts do these calculations. Including this effect raises the apparent total discount even more, as shown in the table. 
reasons. Second, the discount might not be worth the manager's attention when setting retail price if the discount group is small or the discount is small. While that is true when the discount and/or discount group is small, it is not obvious that the manager would be more likely to underrespond than to overrespond to this marginal effect. Analyzing either of these reasons, however, requires knowing the difference in profits between the optimal response and no response to the discount. With $10 \%$ of the population receiving a discount of 0.15 in this case, profits are only $0.06 \%$ lower with no response than with the optimal price response. That increases to a $1.26 \%$ difference if half of the population gets the 0.15 discount. These percentage profit decreases are about eight times larger, however, if the discount is 0.3 rather than 0.15 . While very small discounts to a very small share of consumers may engender no response by the firm - at least in the short run if it has no other reason to adjust price - larger discounts or a larger share of discount customers greatly increase the incentive to reoptimize.

\section{Discount Contracts and Competition}

The illustration above assumed that a firm involved in a discount contract is a monopolist facing a comparatively inelastic firm-level demand curve. The result that the firm responds to the discount contract by raising the retail price is often disregarded in more competitive markets, because it is argued that 
competition will prevent the firm from offsetting the discount in this way. Unfortunately, this is not generally true.

Consider first a simple analysis of a firm that is a small non-strategic seller in a monopolistically competitive market. If the firm-level demand curve is linear, then the discount contract will leave the weighted average price unchanged as discussed above. It is straightforward to show in this case that so long as $\beta$ is a given proportion of the pre-discount price, the proportional impact of the discount on consumer surplus and total surplus is independent of the slope or intercept of the demand curve.

If the demand function is constant-elasticity, more competition makes a discount contract less attractive to consumers. Assume the monopolistically competitive company faces a firmlevel demand curve with an elasticity of -10 . This would imply a $10 \%$ price-cost margin, greater than found in retail gas stations, about that found in supermarkets, and much less than found at restaurants and fast-food outlets. Table 2 presents the impact of a time-limited discount contract in this case. This replicates Table 1, except a demand elasticity of -10 has been substituted for the -3 elasticity used previously and $\beta$ has been adjusted so it remains, alternatively, $10 \%$ and $20 \%$ of the pre-discount retail price.

Far from producing a more favorable outcome, the timelimited discount is more harmful to consumers when imposed 
on a firm facing this very elastic demand. A discount for one period that is $10 \%$ of the original retail price with a demand elasticity of -3 causes total consumer surplus to decline by up to $2 \%$, but with a demand elasticity of -10 , the equivalent contract causes total consumer surplus to fall by up to $12 \% .^{12}$ Profits also decline by a greater proportion when the demand that the firm faces is more elastic, which may be attractive on deterrence grounds when the discount contract is used as punishment for an antitrust violation. Finally, a comparison of tables 1 and 2 indicates that the average price, weighted by share of demand ( $\alpha$ and $1-\alpha$ ), rises much more when the same discount contract is imposed on a firm that faces more elastic demand.

The reason for these results with constant-elasticity demand is the change in the shape of the profit function over the range $\left[(1-x) P^{*},(1+x) P^{*}\right]$ as the elasticity of demand changes. At relatively low elasticities, $P^{*}$ is well above marginal cost and a price change of plus or minus $10 \%$, for instance, has a fairly symmetric effect on profits. At a high elasticity, however, the profit-maximizing price is already close to marginal cost, so a given percentage decrease in price harms profits more than the

12 I use the term "up to" and focus on the maximum changes, because the decline in consumer surplus is zero if the share of the population covered by the discount contract is either $\alpha=0$ or $\alpha=1$. The maximum decline occurs at some intermediate value of $\alpha$, which changes with demand characteristics. As indicated in table 2 , when elasticity is -10 the decline in consumer surplus is greatest at a value above $\alpha=0.5$. 
same percentage increase does. This difference is illustrated in figures $1 \mathrm{a}$ and $1 \mathrm{~b}$, which show the profit functions over a $\left[0.9 P^{*}, 1.1 P^{*}\right]$ range for a firm with a constant marginal cost $(M C=1)$ and facing a constant elasticity demand function with elasticity -3 and -10 , respectively. Thus, when the firm has optimized against a very elastic demand function of this form and then must adapt to a discount contract, it is much more inclined to raise the retail price, i.e., the price to the non-discount group, than to lower the price to the discount group. This asymmetry in the shape of the profit function also means that the profit penalty from doing nothing in response to the discount - maintaining the pre-discount retail price - is much larger in this instance than when the assumed demand elasticity was -3 .

Though the monopolistic competition approach has appeal in its simplicity, it ignores the strategic interactions that could affect a firm's response to the incentives of a discount contract. I next consider more strategic firm behavior in a differentiated duopoly setting and examine the effects of imposing discount contracts on, alternatively, both or just one of the firms.

Throughout this discussion, I assume that there is symmetrically differentiated demand and equal constant marginal cost,

$$
Q_{x}=h\left(P_{x}, P_{y}\right), \quad Q_{y}=h\left(P_{y}, P_{x}\right), \quad c_{x}=c_{y}=c
$$


that yields upward-sloping reaction functions in price and a unique symmetric Nash equilibrium in price, $\hat{P}$, in the absence of discount contracts.

If a time-limited discount contract is then imposed on both firms, it is straightforward to show that the new symmetric equilibrium retail price $(P)$ and discount price $(P-\beta)$ are such that $P-\beta<\hat{P}<P$. To see this, recall that the demand functions of the discount and non-discount group are assumed to differ only in scale, so $\hat{P}$ is the Nash equilibrium price for each group separately. If $P=\hat{P}$, then an increase in $P$ by one firm would have only a second-order effect on its profits from the non-discount group, but since the discount group's price is below the Nash equilibrium price, the firm would gain a first-order profit increase from the discount group by raising $P-\beta$. By similar argument, if $P-\beta=\hat{P}$, then either firm could increase its profits by lowering $P$ and $P-\beta$ since the decline in profits received from the discount group would be second order and the profit gain from the non-discount group would be first order.

A bit more insight can be gotten from considering the optimization of one of the firms explicitly.

$$
\begin{aligned}
\Pi_{x}= & \alpha\left(P_{x}-c\right) h\left(P_{x}, P_{y}\right) \\
& +(1-\alpha)\left(P_{x}-\beta-c\right) h\left(P_{x}-\beta, P_{y}-\beta\right)
\end{aligned}
$$


which yields the first-order condition

$$
\begin{gathered}
\alpha\left[h\left(P_{x}, P_{y}\right)+\left(P_{x}-c\right) h_{1}\left(P_{x}, P_{y}\right)\right] \\
+(1-\alpha)\left[h\left(P_{x}-\beta, P_{y}-\beta\right)\right. \\
\left.+\left(P_{x}-\beta-c\right) h_{1}\left(P_{x}-\beta, P_{y}-\beta\right)\right]=0
\end{gathered}
$$

where $h_{1}$ indicates the derivative with respect to a change in the first argument of the function. Thus, a necessary condition for a symmetric equilibrium is

$$
\begin{aligned}
& \alpha {\left[h(P, P)+(P-c) h_{1}(P, P)\right] } \\
&+(1-\alpha) {[h(P-\beta, P-\beta)} \\
&\left.+(P-\beta-c) h_{1}(P-\beta, P-\beta)\right]=0
\end{aligned}
$$

The expressions inside the square brackets of [6] are the slopes of the profit function of one firm (with respect to the firm's own price only) at the retail and discount prices, respectively, when the firms set identical retail and discount prices.

It is worth noting that if one replaced $P_{y}$ in [5] with $\hat{P}$, so that the other firm did not respond to price changes by firm $x$, then this would be comparable to equation [2], which generated the monopolistic competition outcome of Table 2 when the firm-level demand was assumed to have a constant elasticity of -10 . The derivative of firm $x$ 's profits with respect to its price in that case, $\pi_{1}(P, \hat{P})$, is illustrated by the steepest line in Figure 2. Instead, in [6] the other firm has matched $x$ 's price changes, which will almost certainly lower in absolute 
value the expressions inside of each of the square brackets. ${ }^{13}$ This is illustrated in Figure 2 by the line labelled $\pi_{1}(P, P)$. Still, there is no reason a priori that this will have a larger or smaller proportional impact on the expression inside the first square brackets than on the expression inside the second square brackets. If the price matching by the other firm has an equal proportional impact on the two slopes, then the Nash equilibrium price when both firms are under the discount contract will be the same as the price of only one affected firm in a monopolistically competitive market (facing the same firm-level elasticity as either firm faces in the duopoly model). Thus, under this neutral assumption about the effects of price matching on the marginal profitability of changing price to the discount versus non-discount group, the result is that the a single defendant firm behaves the same when the other firm does not respond as both firms behave when they are both under the discount contract.

To consider the effect of imposing a discount contract on just one firm in a duopoly, it is necessary to make some assumption about the rival's ability to respond to the behavior of the firm that is under the discount contract, which I will call the defendant firm. Must the rival continue to charge a single price or can it price discriminate in favor of buyers that

13 This result obtains in the standard linear-spatial or Dixit-Stiglitz demand models of differentiated duopoly when there is a unique Nash equilibrium price. 
are designated to be covered by the discount contract? If it can charge a different price to designated buyers, can it charge any price differential is chooses, or must it match the terms of the discount contract - e.g., $10 \%$ off or $\$ 25$ off its own retail price - for the designated buyers. It seems unrealistic in most situations to think that the rival can announce, "We give a $\$ 5$ discount if you have a $\$ 10$ discount coupon from the other firm," so I assume for now that the rival either must charge a single price or it must match the terms of the discount contract.

If the rival chooses to match the terms of the discount contract, then the discussion of a discount contract that covers both firms applies immediately: the equilibrium retail price of both firms will not necessarily be greater or less than the retail price of the defendant firm would be under the discount contract if the rival made no change to its price (stayed at $\hat{P}$ ). Similarly, if the rival chose to stick to a single price, it's best response could be to increase or decrease that price from $\hat{P}$ or to leave it unchanged, depending on the weighted average of the slopes of the profits functions (at $\hat{P}$ ) it faces from the discount and non-discount groups once the defendant firm moves.

Even if the rival could price discriminate in favor of the designated buyers without matching the terms of the discount, the defendant firm's prices are likely to be unaffected or only slightly affected by the rival's response. The rival would respond to the defendant firm's (forced) price change by lowering its own price to the designated buyers and raising it to others, 
though its retail price would still be below the defendant firm's and its discount price would still be above that of the defendant firm. The resulting effect on the pricing incentives of the defendant firm are illustrated in figure 2 by the line labeled $\pi_{1}\left(P, P^{* *}\right)$. This would again change the slope of the defendant's profits function on both sides of the optimum, but again the direction of the net effect on its prices - given the discount requirement - is ambiguous.

\section{An Alternative Form of Discount Contract}

While it is clear that a time-limited discount contract has few attractive properties, a small change to these contracts can alter the results substantially. Rather than imposing a discount contract that lasts for a certain period of time, a court could impose a contract that requires a given discount until a certain dollar total is reached. For instance, instead of "a $\$ 10$ discount to every person in the group for two years", a contract could be "a $\$ 10$ discount to each person until he or she has received $\$ 100$ in discounts." Assuming, for simplicity, that the interest rate is zero and no party is liquidity constrained, such a dollarlimited discount contract would be treated as a sunk benefit by buyers and a sunk cost by sellers, and thus would have no effect on the economics of the transactions between them.

Effectively, this would be a $\$ 100$ payment from the seller to each buyer. The $\$ 10$ discount until that total is reached determines only the schedule of debt payment which, if the 
interest rate is zero, is a matter of indifference to the parties. The seller would continue to charge a retail price of $P^{*}$ and each plaintiff would continue to act as if she were paying $P^{*}$, buying $(1-\alpha) f\left(P^{*}\right)$ each period in aggregate, even though the actual transaction payment for each unit would be $P^{*}-$ 10 until the $\$ 100$ limit was reached. Unlike the time-limited discount contract, this arrangement would impose a cost on the seller equal to the benefits gained by the discount buyers. Non-discount buyers would be unaffected.

Though the economics of this analysis are straightforward, the impact can be surprising. Returning to the Acme Widgets example, assume that the designated discount population consists of 1000 individuals, each of whom has been buying 500 units per year at $\$ 1.50$ per unit. Consider a contract that required a $15 \notin$ discount to each of the designated buyers until the buyer has received a total of $\$ 75$ in discounts. Though this appears not to differ substantially from the time-limited discount discussed above - each buyer receiving a $15 \&$ discount on about 500 units - the results would be differ drastically. This approach would not lead to a change in the retail price, would make the designated buyers better off by $\$ 75,000$, would have no effect on other consumers, and would lower Acme's profits by $\$ 75,000$. Acme would bear the full cost of the discount and other consumers would bear none of it. This is in contrast to the time-limited discount which could lower the surplus of consumers other than the designated buyer by as much or more 
than it raised the surplus of the designated buyer, and lower Acme's profits by just a fraction of the total discount, and by just a fraction of the harm to non-discount consumers.

Many recent settlements of antitrust cases that use discount coupons appear at first to fit this description of a dollarlimited discount contract. Although they have some aspects of the contract suggested here, they can fail to live up to this promise due to a number of flaws. Often the coupons have binding time limits on their use. If a buyer does not anticipate buying enough units from the defendant to use up the coupons during the time period (or ever), then the coupons are still effectively time-limited discounts. Similarly, if the coupons are fixed in nominal terms, then inflation and a positive real interest rate reduce the value of the discount over time. Either of these effects will lower the opportunity cost of using the coupon and thus induce an elasticity effect: the discount will cause the consumer to buy more than she would at the full retail price. In addition, some settlements have specified a total liability limit for the firm across all buyers, creating a common pool of benefits for all buyers. Others - the airline case for instance - have pooled the coupons across firms, which changes the incentives for any one firm. These last two difficulties both of which are common-pool problems - are taken up in the following section. 


\section{Dollar-Limited Contracts and Common Pools}

The dollar-limited discounts described in the previous section have attractive properties because each buyer/seiler takes his gain/loss as sunk. Unfortunately, this will sot occur if the total discount limits are pooled among either buyers or sellers. A dollar-limited discount contract with many buyers will induce a common-pool effect if the dollar limit is aggregate rather than set separately for each buying entity. If each buyer is a very small part of the pool, then each will take as exogenous the date at which the discount ends and will behave as if the discount is time-limited rather than dollar-limited, making purchases based on the discounted price, $P-\beta$. The firm's optimization problem is then changed.

Consider one-company agreeing to a dollar-limited aggregate discount that applies to $1-\alpha$ of a very large buying population so that any one member of the designated discount group would take the date at which the discount ends as exogenous (though possibly random). Assume that the court has told a company that it must give a discount of $\beta$ to every purchase by a designated buyer until it has given aggregate discounts of $D$. Each designated buyer then takes the discounted price as the full price on which she should base her buying decision. Since $f(\cdot)$ gives the per-period demand, the time until the discount expires will then be:

$$
t=\frac{D}{\beta(1-\alpha) f(P-\beta)}
$$


where $P$ is the retail price chosen while the discount is in effect. Assume that the interest rate is still zero and that the firm will exist for $T$ periods with $t<<T$ so that $T$ presents no constraint on the firm's behavior. The firm's optimization problem is then

$$
\begin{aligned}
\max \Pi= & t \cdot[(P-c) \alpha f(P)+(P-\beta-c)(1-\alpha) f(P-\beta)] \\
& +(T-t) \cdot\left[\left(P^{*}-c\right) f\left(P^{*}\right)\right]
\end{aligned}
$$

where $P^{*}$ is still the unconstrained profit maximizing price. The first term in this expression is the profits earned while the discount is in effect and the second is the profits after the discount ends. If $t$ were exogenous, this would be a time-limited discount. There is an additional effect, however, because $t$ is endogenous.

$$
\begin{aligned}
\frac{\mathrm{d} \Pi}{\mathrm{d} P}=t\{\alpha[ & \left.f(P)+f^{\prime}(P)(P-c)\right] \\
& \left.+(1-\alpha)\left[f(P-\beta)+f^{\prime}(P-\beta)(P-\beta-c)\right]\right\} \\
& +\frac{\mathrm{d} t}{\mathrm{~d} P}[(P-c) \alpha f(P)+(P-\beta-c)(1-\alpha) f(P-\beta) \\
& \left.-\left(P^{*}-c\right) f\left(P^{*}\right)\right]=0
\end{aligned}
$$

The first line of this expression alone is $t$ times the time-limited discount first-order condition and would be equal to zero at the price that is profit-maximizing under a time-limited discount. The second line takes into account the endogeneity of $t$ : a higher price lowers aggregate dollar discount per period and extends the time period over which the discount must be 
offered, i.e., $\frac{\mathrm{d} t}{\mathrm{~d} P}=-\frac{D f^{\prime}(P-\beta)}{\beta(1-\alpha)[f(P-\beta)]^{2}}$ is positive (so long as demand slopes down). The remainder of the second line is the per-period profits when the discount must be offered minus the unconstrained per-period profits, and therefore must be negative. Thus, the second line is negative, so the derivative of profits with respect to price would be negative at the price that would result from a time-limited discount. If the profit function is concave, this means that the profit maximizing retail price will be lower than under a time-limited discount.

But not necessarily much lower. Table 3 gives the profitmaximizing prices for a range of parameters assuming the same constant-elasticity demand curve and constant marginal cost as in table 1 . The price chosen with a dollar-limited discount and many buyers is much closer to the time-limited discount outcome than to the "non-distorting" outcome from a dollarlimited discount with no common-pool effect among buyers.

The common-pool effect among buyers moves the outcome towards the time-limited discount because each designated buyer perceives the price of the good as having declined and responds by purchasing more. This elasticity effect is absent if each buyer believes the total dollar discount she will receive is fixed, as was the case with the dollar-limited discount in the previous section. The endogeneity of $t$, which exerts a downward effect on $P$, turns out to have little impact. This is not too surprising, since $\frac{\mathrm{d} t}{\mathrm{~d} P}$ in equation [9] is multiplied by a profit change that is second order for small $\beta$ or for $\alpha$ near zero 
or one. Price is just slightly lower than under the time-limited discount and the time to reach the same total dollar discount as in Table 1 is nearly as large. Total lost profits in this case $(\Delta \Pi /$ per $\cdot$ Periods $)$ are smaller than under the time-limited discount - this must be the case since the firm has the option of setting the same price as under the time-limited discount and obtaining the same outcome - but the difference is so small between the cases illustrated in Table 3 and Table 1 that it is not apparent in some of the rows.

\section{A Common Discount Pool Among Many Firms}

If a dollar-limited discount contract is agreed to by a single firm, then the firm knows that, roughly speaking, each time it makes an additional discount sale today it "frees up" one additional sale of its own in the future to take place at full price. If, however, many firms are part of a common dollarlimited discount pool, then each time any one of them makes an additional discount sale today it "frees up" one additional sale in the future to take place at full price, but that additional full-price sale may not be its own. If a firm has $30 \%$ of the sales by the firms that are part of the discount pool, then an additional sale by the firm today only frees up, in expectation, 0.3 of a sale of its own in the future to take place at full price. If a firm is an extremely small part of the pool, then it will take the time at which the discount requirement ends as virtually exogenous. 
To analyze this effect, assume that there is no common pool among discount buyers, but that many firms participate in a common pool to provide the discounts. To focus only on the effect of the common discount pool among sellers, assume that the firms sell in different (non-competing) markets. Then a firm that is an extremely small part of the pool will take $t$ as given and face the maximization problem:

$$
\begin{aligned}
\max \Pi & =t \cdot[(P-c) \alpha f(P)+(P-\beta-c)(1-\alpha) f(P)] \\
& +(T-t) \cdot\left[\left(P^{*}-c\right) f\left(P^{*}\right)\right]
\end{aligned}
$$

The firm now acts as if $\frac{\mathrm{d} t}{\mathrm{~d} P}=0$ so this looks very much like the optimization under the time-limited discount, except each discount consumer recognizes that her total cost of each purchase is the full retail price and in aggregate they buy only $(1-\alpha) f(P)$. The first-order condition:

$$
\begin{aligned}
\frac{\mathrm{d} \Pi}{\mathrm{d} P}=t\left\{\alpha\left[f(P)+f^{\prime}(P)(P-c)\right]\right. \\
\left.+(1-\alpha)\left[f(P)+f^{\prime}(P)(P-\beta-c)\right]\right\}=0
\end{aligned}
$$

can be rewritten as

$$
(P-c) f^{\prime}(P)+f(P)=(1-\alpha) \beta f^{\prime}(P)
$$

The lefthand side of [11'] is the unconstrained first-order condition for pricing. The righthand side is negative, so the optimum will occur at a downward sloping point on the original profit function, which is a price above $P^{*}$ if the profit function is concave. Comparison of [11] and [2] reveals that the solution 
in this case can be above or below the price the results from a time-limited discount. ${ }^{14}$

Table 4 illustrates this using the same constant-elasticity demand curve and constant marginal cost as in Tables 1 and 3 . As with the common-pool problem on the part of consumers, the seller common-pool problem alone raises the retail price under a dollar-limited discount contract by about as much as a time-limited contract when demand is constant elasticity. In fact, the loss in consumer surplus to achieve the same total dollar discount as under a one-period time-limited discount contract ( $\triangle C S /$ per multiplied by the number of periods necessary to reach the total dollar discount) can be much greater in this case, because this discount contract is in effect for much longer. The reason that it takes so much longer to achieve the same total dollar discount in this case is that the designated discount buyers consider the total discount as a sunk gain and buy as if they were facing the full retail price. Under this seller common-pool problem, the firms are worse off than under the simple dollar-limited discount contract with no common-pool issue. The loss in profits in this case $(\Delta \Pi /$ per multiplied by the number of periods necessary to reach the total dollar discount) is greater than the total dollar discount. The firms would be

\footnotetext{
14 The price will be below the time-limited discount result if and only if

$$
f(P-\beta)-f(P)+(P-\beta-c)\left[f^{\prime}(P-\beta)-f^{\prime}(P)\right]>0
$$
}

which will hold for linear demand, but not necessarily for more convex demand functions. 
better off if they simply divided the liability pool ex ante and eliminated this common pool problem.

If a firm is a significant part of the whole pool, then it will take $\frac{d t}{d P}>0$, though still less than its value when there is no free riding among firms. As its share of the output of all firms in the pool rises, its implicit $\frac{\mathrm{d} t}{\mathrm{~d} P}$ will rise and its profit-maximizing $P$ under the discount contract will fall, until $P=P^{*}$ if only one firm is covered by the discount contract. ${ }^{15}$

Finally, for completeness, it is worth noting that if an extreme common-pool problem exists among both buyers and sellers, so that each participant in the market takes $t$ as exogenous, the result is the same as obtains under the time-limited discount.

\section{Analyzing Some Recent Settlements}

It is easiest to illustrate the practical implications of this analysis by applying it to some of the recent large legal settlements. It appears, for instance, that the Xerox settlement comes close to being an ideal coupon settlement from a public policy viewpoint: giving Xerox very little incentive to raise its price, allowing the plaintiffs to collect nearly the full benefit of the settlement, and having almost no effect on other buyers. There should be an active resale market in Xerox's transferable

15 This will also be the result if each defendant in the case has its own separate discount limit. 
certificates, so the opportunity cost of using such a certificate is the revenue one could collect by selling it in the resale market. The price in this resale market is probably nearly the full dollar value of the certificate, though there is certainly some spread between the selling price and the redemption value. ${ }^{16}$ Thus, a user of a coupon will probably display very little elasticity effect, behaving as if she is paying $P$, not $P-C$, where $C$ is the face value of the coupon. The transferability also means that any time limit on the use of the coupons is less likely to be binding and the redemption rate will be very high. ${ }^{17}$ Finally, the case and the settlement involved only Xerox, so there is no common-pool effect on the seller's side.

Still, even this attractive settlement has some weaknesses that will be present in implementing nearly any coupon settlement, but will vary in importance. Delay in using coupons not only causes loss due to inflation and the real interest rate, it also causes expected loss from the probability that the certificate will be lost or forgotten. If consumers ignored these pos-

16 In 1980 , when many airline issued $\$ 50$ transferable coupons, there was an active resale market with most transactions taking place at about $\$ 40$. That, however, was a consumer market, so transaction costs were probably a larger proportion of the coupon value than would be the case here. Furthermore, many coupons probably changed hands in less formal markets, and at lower transaction costs.

17 Redemption rates for trading stamps in the 1960 s, which were transferable, were generally around $95 \%$. These stamps had no expiration date, but they also probably had much lower value compared to the hassle of using them - endless hours of pasting stamps into books than the Xerox certificates. 
sible losses and still bought $f(P)$ each period, then inflation, interest and lost coupons would simply reduce the net benefit to consumers and cost to the firm. Some consumers, however, will respond by buying units that they otherwise would not have bought, causing an elasticity effect which, as shown earlier, will give the firm an incentive to raise its retail price.

The airline settlement also at first appears to satisfy the ideal criteria. Coupons are issued to individuals and the liability limit is the total redemption value of the coupons. The coupons, however, have fairly short expirations (three years), significant use restrictions, and are not transferable (except among immediate family). The proportion of beneficiaries who end up using all of their coupons before expiration will give some indication of whether this resembled more closely a timelimited or a dollar-limited discount. ${ }^{18}$ If the time limit were binding for most coupon recipients, then results reflected in table 1 are most applicable. The airlines would lose little from the settlement and the net effect on consumers could be positive or negative, but would certainly be much less than the $\$ 400$ million gain that is most often stated.

Besides the problems from time limitation on the coupons, most of the coupons are good for trips on any one of seven set-

18 This information is dispositive only if a large percentage of beneficiaries are left with unused coupons. If most buyers use all of their coupons, this could be because the time constraint was non-binding or because the elasticity effect of the (time-limited) discount was great enough to cause full use of the coupons. 
tling airlines, creating a common-pool problem among sellers. ${ }^{19}$ Interestingly, Northwest Airlines refused to be part of this group and instead cut a separate parallel deal in which it issued Northwest-specific coupons. If the time limitation were not a binding constraint, then the common-pool problem could make the other airlines significantly worse off than Northwest, as indicated by the analysis around Table 4 . If the time limit is binding for most consumers, then the common-pool effect among sellers may be irrelevant.

The GM settlement - reported to be worth $\$ 6$ billion because $\$ 1000$ coupons are to be mailed to 6 million truck owners - would be the most suspect on public policy grounds. Because there is a significant penalty for transferring the $\$ 1000$ coupons, ${ }^{20}$ they would almost certainly generate an elasticity effect. This is particularly true since many of the plaintiffs were probably not planning to buy another GM truck in the foreseeable future. This points out the problem with using coupon settlements for infrequently-purchased goods.

In fact, a large proportion of the coupons will probably unused, creating no value for consumers and no cost to GM. The proportion of all buyers that use a coupon would determine the

19 The airlines in the common pool are Alaska, American, Continental, Delta, TWA United, and USAir.

20 If a coupon is transferred outside of the recipient's immediate family, it decreases in discount value to $\$ 500$, can be used on only on one specific model of pickup truck instead of any GM truck, and can no longer be used in combination with any other promotion. 
effective size of $1-\alpha$ at any point in time. If that proportion were small, the net consumer surplus effect - positive or negative - would also be proportionally small. Regardless of $\alpha$, if buyers with the coupons based their purchase decision on the after-discount price, the settlement would have a very minor impact on GM's profits, but would likely impose a substantially larger burden on non-discount buyers of GM trucks.

A 1991 settlement of a case against Nintendo for vertical price-fixing on video game consoles demonstrates some other pitfalls of coupon settlements. The settlement required Nintendo to distribute up to 5 million coupons good for $\$ 5$ off on purchase of a Nintendo game cartridge, which generally cost $\$ 20$ to $\$ 60$ each. Such a small coupon value is likely to segment consumers into a group that finds it worth their time to acquire and use the coupons and a group that does not. The plaintiffs attempted to avoid the possibility of offsetting price increases by requiring Nintendo not to raise the wholesale price of these cartridges over the life of the coupons. The coupons, however, were good only on the Nintendo's 8-bit computer games (the 8bit consoles were the focus of the case), but were released just a few months before this technology was made obsolete by 16-bit systems. Thus, the price of 8-bit cartridges was quite possible would have fallen in the absence of the coupons. Finally, the 18-month time limit on the coupons and the impending release of 16-bit systems meant that the coupons were probably not treated as sunk gains by most consumers and therefore almost 
certainly created an elasticity effect, to the extent they were used at all. ${ }^{21}$

\section{Conclusion}

Before approving a settlement of a class-action lawsuit, a judge must determine that the parties to the case are treated fairly in light of the evidence. Neither the parties' attorneys nor the judge is required to consider the impact of the settlement on others in the economy. Yet, this analysis has shown that other buyers in markets affected by "coupon settlements" to legal disputes are likely to be the biggest losers; the loss to buyers who are not plaintiffs can dwarf the loss to the defendant from these settlements. Furthermore, contrary to common wisdom - and legal arguments in some of these cases - competition among sellers in these markets is not likely to lessen the relative impact on non-plaintiff consumers versus defendants.

With careful restructuring, however, discount contracts generally, and coupons in particular, can be used in legal settlements without giving defendant firms an incentive to raise the retail price. The critical factors to meet this goal are that (1) there is no (binding) time limit on the use of the coupons, (2) there is no aggregate limit on the defendant's liability that

21 Economists must note with irony that this form of reimbursement to plaintiffs was said to be chosen because previous attempts to rebate cash to class-members in suits against Minolta (cameras) and Panasonic (stereos) drew less than a $10 \%$ response rate. 
causes an effective time limit from the perspective of any one coupon holder, and (3) there is no pooling of liability across multiple defendants.

Of course, discount contracts in legal settlements may be attractive precisely because they place the primary burden on individuals who are not a party to the case. The fact that the gain discount contracts create for the plaintiffs is usually larger than the loss to defendants certainly aids in reaching an agreement. Furthermore, in determining the compensation allowed the plaintiffs' attorneys in a private class-action lawsuit, the court considers the value of the settlement. If it believes that a coupon settlement is worth $\$ 400$ million to the plaintiffs (as was argued in the airline case), the court is likely to approve a much higher fee for the lawyers of the class than if it realizes the gains to the plaintiffs will be smaller due to price increases and unused coupons or that the net gain to all consumers might very well be zero or negative. The restructuring of such settlements that I suggest here would eliminate the burden placed on non-participants to the case, but it would also eliminate the net gain to the litigating parties and the inflated valuation of the settlement, which may have been the primary reasons for using discount contracts to begin with.

The results here also have implications for discount contracts that do not stem from lawsuits. When large institutional buyers negotiate discount contracts through bilateral bargaining, it is not necessarily the case that these discounts are re- 
lated to higher firm- or market-level elasticities. If these discounts are due instead to tougher bargaining or lower transaction ccsts (on a per-unit basis) of engaging in bargaining, then the seller would still like to charge these designated buyers as high or higher prices than the remaining consumers. When the discount contract then forces the seller to discount to designated buyers, the result of these time-limited agreements correspond to the analysis in sections II and III: gains to the designated discount buyers are paid for primarily through losses to non-discount consumers. 


\section{REFERENCES}

Barrett, Paul M., "Nintendo's Latest Novelty Is a Price-Fixing Settlement," Wall Street Journal, April 11, 1991.

Lavin, Douglas, "GM Settlement is Cleared in Suit on Pickup Trucks, Wall Street Journal, December 17, 1993.

Lambert, Wade, "GM Pickup Settlement," Wall Street Journal, June 27, 1994, p. B4.

Lewin, Tamar, "Cuisinart's Deal in Pricing Suit," New York Times, July 20, 1983, p. D1.

"Circa Pharmaceuticals Inc.: Drug Company will Settle Bolar Claims, Issue Coupons" Wall Street Journal, July 11, 1994, p. B4.

Geyelin, Milo, "Xerox Agrees to Vouchers in Settlement," Wall Street Journal, December 8, 1993, p. B9. 
Table 1: Illustration of One-Period Discount Contract

(Demand: $Q=P^{\epsilon}, \epsilon=-3$. Cost: $M C=1$ )

No-Discount Baseline (per period)

$\mathrm{P}=1.50$, Consumer Surplus $=0.2222, \Pi=0.1481$, Total Surplus $=0.3704$

Outcome with Discount Contract

$\begin{array}{lrcrrrrrr}\beta & \alpha & P_{r} / P_{d} & \Delta C S_{r} / \text { per } & \Delta C S_{d} / \text { per } & \Delta \Pi / \text { per } & \Delta T S / \text { per } & \text { Periods } & \text { Tot } \$ \text { Disc } \\ 0.15 & 0.9 & 1.522 / 1.372 & -0.0056 & +0.0044 & -0.0005 & -0.0018 & 1.000 & 0.0058 \\ 0.15 & 0.7 & 1.559 / 1.409 & -0.0115 & +0.0089 & -0.0010 & -0.0036 & 1.000 & 0.0161 \\ 0.15 & 0.5 & 1.590 / 1.440 & -0.0122 & +0.0095 & -0.0011 & -0.0038 & 1.000 & 0.0251 \\ & & & & & & & & \\ 0.3 & 0.9 & 1.562 / 1.262 & -0.0156 & +0.0092 & -0.0024 & -0.0088 & 1.000 & 0.0149 \\ 0.3 & 0.7 & 1.647 / 1.347 & -0.0265 & +0.0160 & -0.0042 & -0.0147 & 1.000 & 0.0368 \\ 0.3 & 0.5 & 1.705 / 1.405 & -0.0252 & +0.0155 & -0.0040 & -0.0137 & 1.000 & 0.0541\end{array}$

$P_{r}=$ Retail Price. $P_{d}=$ Discount Price.

$\beta=P_{r}-P_{d}$ required.

$\alpha=$ Purchase share of non-discount group (when all pay the same price).

$\Delta C S_{r} /$ per $=$ Change in Consumer Surplus per period of buyers not covered by discount. $\Delta C S_{d} /$ per $=$ Change in Consumer Surplus per period of buyers covered by discount.

$\Delta \Pi=$ Change in firm profits. $\Delta T S=$ Change in Total Surplus. 
Table 2: Illustration of One-Period Discount Contract with One Monopolistically Competitive Discount Seller

(Demand: $Q=P^{\epsilon}, \epsilon=-10$. Cost: $M C=1$ )

No-Discount Baseline (per period)

$\mathrm{P}=1.111$, Consumer Surplus $=0.0430, \Pi=0.0387$, Total Surplus $=0.0818$

Outcome with Discount Contract

$$
\beta
$$

$$
\alpha \quad P_{r} / P_{d} \quad \Delta C S_{r} / \text { per }
$$

$$
\triangle C S_{d / \mathrm{per}}
$$

$\Delta \Pi / \mathrm{per} \quad \Delta T S / \mathrm{per}$

Periods

Tot $\$$ Disc

$0.111 \quad 0.9 \quad 1.140 / 1.028$

$-0.0079+0.0043$

$-0.0026$

$-0.0061$

1.000

0.0084

$\begin{array}{lll}0.111 & 0.7 & 1.173 / 1.062\end{array}$

$-0.0117+0.0064$

$-0.0040$

$-0.0093$

1.000

0.0182

$0.111 \quad 0.5 \quad 1.194 / 1.083$

$-0.0103+0.0056$

$-0.0036$

$\begin{array}{ll}-0.0082 & 1.000\end{array}$

0.0251

0.222

$\begin{array}{ll}0.9 & 1.223 / 1.001\end{array}$

$-0.0224$

$+0.0068$

$-0.0119$

$-0.0122$

$-0.0275$

$-0.0276$

1.000

0.0221

$\begin{array}{llll}0.222 & 0.7 & 1.284 / 1.062\end{array}$

$-0.0219+0.0066$

$-0.0094$

$-0.0210$

1.000

0.0368

0.0488

$P_{r}=$ Retail Price. $P_{d}=$ Discount Price.

$\beta=P_{r}-P_{d}$ required.

$\alpha=$ Purchase share of non-discount group (when all pay the same price).

$\Delta C S_{r} /$ per $=$ Change in Consumer Surplus per period of buyers not covered by discount.

$\Delta C S_{d} /$ per $=$ Change in Consumer Surplus per period of buyer covered by discount.

$\Delta \Pi=$ Change in firm profits. $\Delta T S=$ Change in Total Surplus. 


\section{Table 3: Illustration of Dollar-Limited Discount Contract with Many Common-Pool Discount Buyers \\ (Demand: $Q=P^{\epsilon}, \epsilon=-3$. Cost: $M C=1$ )}

No-Discount Baseline (per period)

$\mathrm{P}=1.50$, Consumer Surplus $=0.2222, \Pi=0.1481$, Total Surplus $=0.3704$

Outcome with Discount Contract

$\begin{array}{lrcrrrrrr}\beta & \alpha & P_{r} / P_{d} & \Delta C S_{r} / \text { per } & \Delta C S_{d} / \text { per } & \Delta \Pi / \text { per } & \Delta T S / \text { per } & \text { Periods } & \text { Tot } \$ \text { Disc } \\ 0.15 & 0.9 & 1.519 / 1.369 & -0.0049 & +0.0045 & -0.0005 & -0.0010 & 0.992 & 0.0058 \\ 0.15 & 0.7 & 1.553 / 1.403 & -0.0105 & +0.0095 & -0.0010 & -0.0020 & 0.989 & 0.0161 \\ 0.15 & 0.5 & 1.584 / 1.434 & -0.0115 & +0.0105 & -0.0011 & -0.0021 & 0.987 & 0.0251 \\ & & & & & & & & \\ 0.3 & 0.9 & 1.548 / 1.248 & -0.0121 & +0.0099 & -0.0024 & -0.0047 & 0.965 & 0.0149 \\ 0.3 & 0.7 & 1.623 / 1.323 & -0.0227 & +0.0190 & -0.0043 & -0.0080 & 0.947 & 0.0368 \\ 0.3 & 0.5 & 1.684 / 1.384 & -0.0229 & +0.0195 & -0.0041 & -0.0075 & 0.955 & 0.0541\end{array}$

$P_{r}=$ Retail Price. $P_{d}=$ Discount Price.

$\beta=P_{r}-P_{d}$ required.

$\alpha=$ Purchase share of non-discount group (when all pay the same price).

$\Delta C S_{r} /$ per $=$ Change in Consumer Surplus per period of buyers not covered by discount .

$\Delta C S_{d} /$ per $=$ Change in Consumer Surplus per period of buyer covered by discount.

$\Delta \Pi=$ Change in firm profits. $\Delta T S=$ Change in Total Surplus. 


\section{Table 4: Illustration of Dollar-Limited Discount Contract with Many Common-Pool Sellers}

(Demand: $Q=P^{\epsilon}, \epsilon=-3$. Cost: $M C=1$ )

No-Discount Baseline (per period)

$\mathrm{P}=1.50$, Consumer Surplus $=0.2222, \Pi=0.1481$, Total Surplus $=0.3704$

Outcome with Discount Contract

$\begin{array}{lrcrrrrrr}\beta & \alpha & P_{r} / P_{d} & \Delta C S_{r} / \text { per } & \Delta C S_{d} / \text { per } & \Delta \Pi / \text { per } & \Delta T S / \text { per } & \text { Periods } & \text { Tot } \$ \text { Disc } \\ 0.15 & 0.9 & 1.523 / 1.373 & -0.0059 & +0.0036 & -0.0044 & -0.0066 & 1.365 & 0.0058 \\ 0.15 & 0.7 & 1.568 / 1.418 & -0.0131 & +0.0061 & -0.0125 & -0.0195 & 1.378 & 0.0161 \\ 0.15 & 0.5 & 1.613 / 1.463 & -0.0150 & +0.0029 & -0.0200 & -0.0320 & 1.403 & 0.0251 \\ & & & & & & & & \\ 0.3 & 0.9 & 1.545 / 1.245 & -0.0115 & +0.0069 & -0.0085 & -0.0131 & 1.832 & 0.0149 \\ 0.3 & 0.7 & 1.635 / 1.335 & -0.0246 & +0.0100 & -0.0235 & -0.0381 & 1.787 & 0.0368 \\ 0.3 & 0.5 & 1.725 / 1.425 & -0.0271 & +0.0213 & -0.0361 & -0.0611 & 1.851 & 0.0541\end{array}$

$P_{r}=$ Retail Price. $P_{d}=$ Discount Price.

$\beta=P_{r}-P_{d}$ required.

$\alpha=$ Purchase share of non-discount group (when all pay the same price).

$\triangle C S_{r} /$ per $=$ Change in Consumer Surplus per period of buyers not covered by discount.

$\Delta C S_{d} /$ per $=$ Change in Consumer Surplus per period of buyer covered by discount.

$\Delta \Pi=$ Change in firm profits. $\Delta T S=$ Change in Total Surplus. 


\section{Profit Function over $\left[0.9 P^{\star}, 1.1 P^{\star}\right]$}

Constant Elasticity Demand of $-3, M C=1$

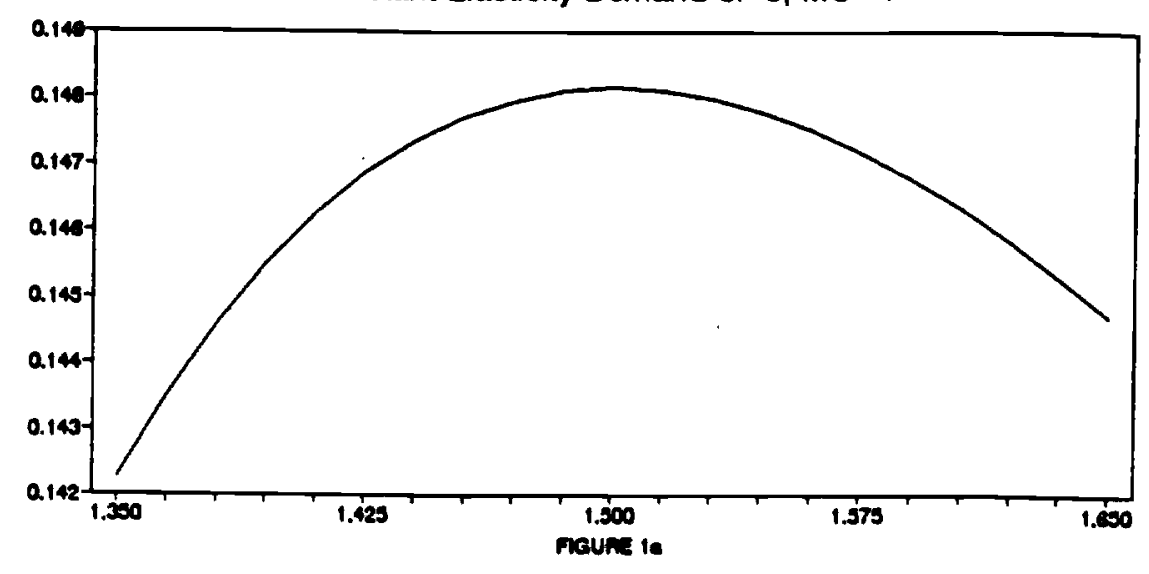

Profit Function over $\left[0.9 P^{\star}, 1.1 P^{\star}\right]$

Constant Elasticity Demand of $-10, M C=1$

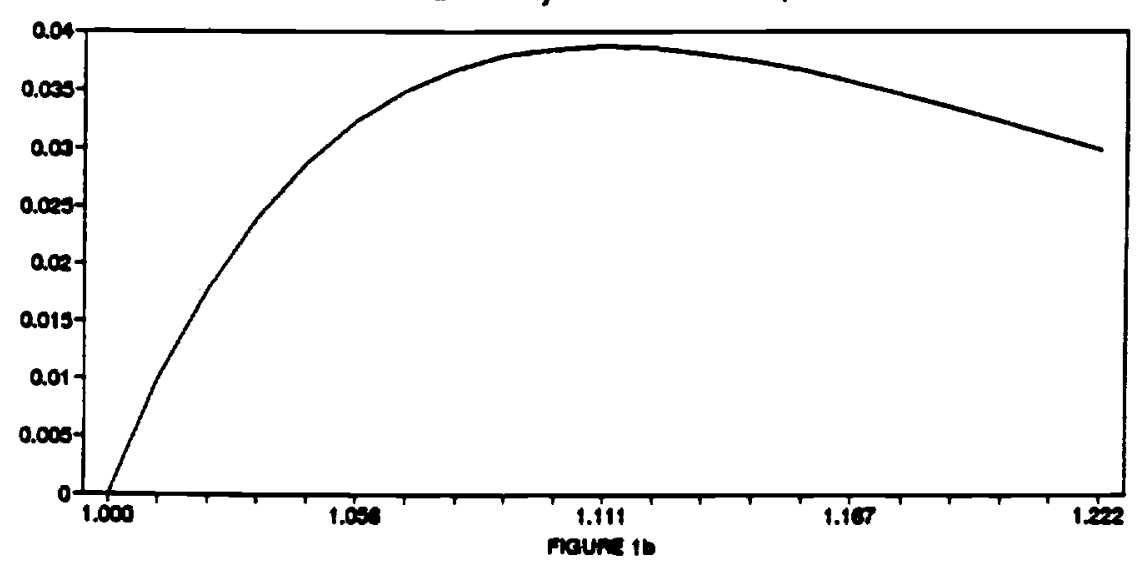


Derivative of One Firm's Profits With Respect to Its Own Price In Differentiated Duopoly Model $\left(\pi_{1}(\cdot, \cdot)\right)$

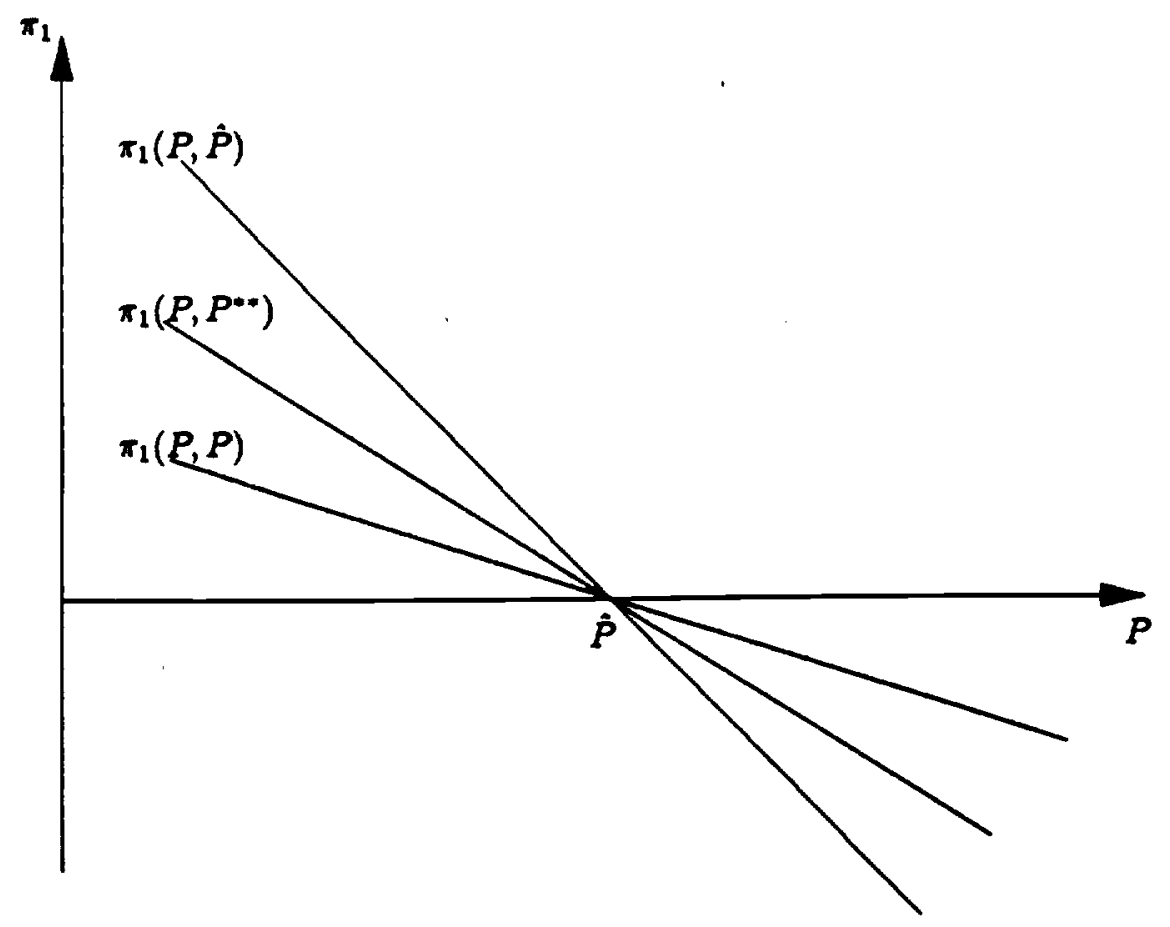

FIGURE 2 